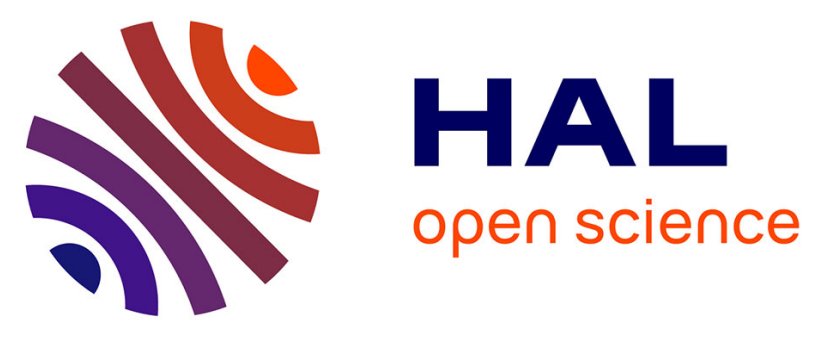

\title{
Design and preparation of market baskets of EU commercial baby foods for the assessment of infant exposure to food chemicals and to their effects
}

Raffaela Piccinelli, Marchela Pandelova, Cinzia Le Donne, Marika Ferrari, Karl-Werner Schramm, Catherine Leclercq

\section{To cite this version:}

Raffaela Piccinelli, Marchela Pandelova, Cinzia Le Donne, Marika Ferrari, Karl-Werner Schramm, et al.. Design and preparation of market baskets of EU commercial baby foods for the assessment of infant exposure to food chemicals and to their effects. Food Additives and Contaminants, 2010, 27 (10), pp.1337. 10.1080/19440049.2010.489913 . hal-00608722

\section{HAL Id: hal-00608722 \\ https://hal.science/hal-00608722}

Submitted on 14 Jul 2011

HAL is a multi-disciplinary open access archive for the deposit and dissemination of scientific research documents, whether they are published or not. The documents may come from teaching and research institutions in France or abroad, or from public or private research centers.
L'archive ouverte pluridisciplinaire HAL, est destinée au dépôt et à la diffusion de documents scientifiques de niveau recherche, publiés ou non, émanant des établissements d'enseignement et de recherche français ou étrangers, des laboratoires publics ou privés. 


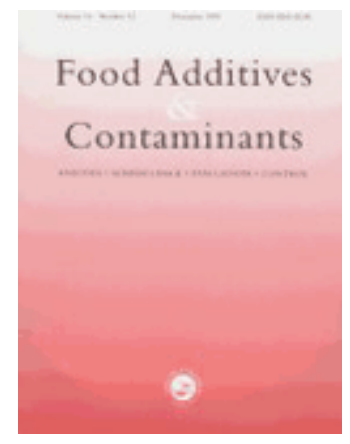

\section{Design and preparation of market baskets of EU commercial baby foods for the assessment of infant exposure to food chemicals and to their effects}

\begin{tabular}{|c|c|}
\hline Journal: & Food Additives and Contaminants \\
\hline Manuscript ID: & TFAC-2010-013.R1 \\
\hline Manuscript Type: & Original Research Paper \\
\hline $\begin{array}{r}\text { Date Submitted by the } \\
\text { Author: }\end{array}$ & 23-Apr-2010 \\
\hline Complete List of Authors: & $\begin{array}{l}\text { Piccinelli, Raffaela; National Research Institute on Food and } \\
\text { Nutrition, Applied Sciences } \\
\text { Pandelova, Marchela; Helmholtz Zentrum München Research, } \\
\text { Center for Environmental Health, Institute of Ecological Chemistry } \\
\text { Le Donne, Cinzia; National Research Institute on Food and } \\
\text { Nutrition, Applied Sciences } \\
\text { Ferrari, Marika; National Research Institute on Food and Nutrition, } \\
\text { Applied Sciences } \\
\text { Schramm, Karl-Werner; Helmholtz Zentrum München Research, } \\
\text { Center for Environmental Health, Institute of Ecological Chemistry } \\
\text { Leclercq, Catherine; National Research Institute on Food and } \\
\text { Nutrition, Applied Sciences }\end{array}$ \\
\hline Methods/Techniques: & Total diet, Exposure \\
\hline Additives/Contaminants: & Hormones, Food contact materials, Metals, Pesticide residues \\
\hline Food Types: & Baby food, Infant formulae \\
\hline
\end{tabular}

\section{SCHOLARONE \\ Manuscripts}




\section{Design and preparation of market baskets of $\mathrm{EU}$ commercial baby}

\section{2 foods for the assessment of infant exposure to food chemicals and to}

\section{3 their effects}

4

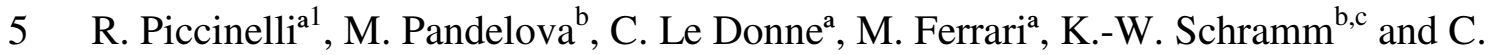

6 Leclercq $^{\mathrm{a}}$ 7

$8 \quad$ anational Research Institute on Food and Nutrition, Rome, Italy

$9{ }^{b}$ Helmholtz Zentrum München, Research Center for Environmental Health, Institute of

10 Ecological Chemistry, Neuherberg, Germany

$11{ }^{\mathrm{c}}$ TUM, Wissenschaftszentrum Weihenstephan für Ernährung und Landnutzung,

12 Department für Biowissenschaften, Freising, Germany

13

14

15 
1 Abstract:

2 The assessment of acute and chronic dietary exposure to contaminants in baby foods is 3 needed to ensure healthy infant growth. Monthly EU market baskets of commercial baby 4 foods were designed for the first 9 months of life by the "babyfood" study group of the 5 CASCADE Network of Excellence for the specific purpose of assessing exposure to 6 potentially toxic substances in infants fed with such foods. The present paper reports the 7 different steps that led to the preparation of monthly pooled samples of commercial baby 8 foods ("Infant formulae and follow-on formulae", and "Other baby foods") that may 9 constitute the extreme case of the diet for an infant that would not be breast fed at all. 10 Several market baskets were generated for an "average EU infant" and for infants of 4 11 selected countries (Italy, Sweden, Spain and Slovakia), fed with either milk infant 12 formulae, soy infant formulae or hypoallergenic infant formulae and weaned (at the $5^{\text {th }}$ 13 month) with commercial baby foods and beverages available on the EU market. Market 14 share data for 2007 for baby foods were used to design the baskets. Holding companies 15 and the name of all their products were identified. Monthly diets for EU infants were 16 elaborated in terms of food categories (e.g. infant cereals) of typologies of products (e.g. 17 infant cereals without gluten) and of a specific product. The number of baskets generated 18 was 30 for "Infant formulae and follow-on formulae" (including 62 products) and 13 for 19 "Other baby foods" (including 35 products). These market baskets were designed to be 20 used for the determination of certain contaminants and nutrients in the diet of EU infants 21 and for the assessment of their effects on infant health.

Keywords: Market basket, baby foods, infant formulae, contaminants, EU 


\section{Introduction}

Commercial food products specifically designed for infants (0-12 months) are available on the market in all EU countries. Their composition is regulated by two specific directives related to "infant formulae and follow-on formulae" (European Commission 2006a) and to "cereal-based foods and baby foods for infants and young children" (European Commission 2006b). In the present paper the terms "Infant formulae and follow-on formulae" and "Other baby foods" (including all others solid and liquid commercial products designed for infants) are used to refer to these two groups of products. According to the legislation, "Infant formulae" (sometimes called "starting formulae") are used during the first months of life and satisfying by themselves the nutritional requirements of such infants until the introduction of appropriate complementary feeding", whereas "follow-on formulae" are used by infants when appropriate complementary feeding is introduced" (European Commission 2006a).

The lifestyles changes encourage an increasing number of women to work while their children are young and parents have generally little time to prepare home-cooked foods for infants. This factor, together with manufacturer's innovation, probably contributed to the baby foods market growth which was observed in recent years (Research and Market 2006 [internet]). No more than $35 \%$ of infants worldwide are exclusively breastfed during the first four months of life (WHO 2003).

Therefore, in order to assess dietary exposure to potentially toxic substances in infants, it appears crucial to monitor their exposure through "Infant formulae and follow-on formulae" and "Other baby foods".

Infants are especially vulnerable to the acute, sub-acute and chronic effects of ingestion of chemical hazards. The nervous, reproductive, digestive, respiratory and immune systems of infants are developing.

Moreover, dietary exposure of infants to chemical hazards tends to be higher than that of other population groups. In fact, the average energy requirement of an infant aged 0 to 9 months ranges from 0.40 to $0.48 \mathrm{MJ} / \mathrm{kg}$ body weight i.e. three times that of a sedentary adult aged 3059 years which is $0.14 \mathrm{MJ} / \mathrm{kg}$ bw in males (10.7 MJ for $75 \mathrm{~kg}$ ) and $0.13 \mathrm{MJ} / \mathrm{kg}$ bw in females (8.3 MJ for $62 \mathrm{~kg}$ ) (Commission of the European Communities 1993). Therefore, when the concentration of a chemical is similar in the diet of infants and adults, the dietary exposure of infants is three times that of adults.

In the EU legislation on "Infant formulae and follow-on formulae" and "Other baby foods" there are specific provisions about hygiene, use of food additives, presence of some contaminants and on the use of materials intended to come into contact with foods. These 
1 provisions are aimed to reduce the potential dietary exposure of infants to a number of 2 microbiological and chemical hazards.

However there are no provisions in relation to a number of important endocrine disruptors (with the exception of provisions for pesticides).

Within the frame of the EU funded project CASCADE ("Chemicals as contaminants in 6 the food chain"; project website: www.cascadenet.org) a specific integrated study called 7 "Babyfood" was performed. The main objective of this study was to provide information on dietary exposure through baby foods to a limited number of endocrine disruptors in the EU. The target substances were bisphenol A (BPA), vinclozolin, polychlorinated dibenzo-p-dioxins and

\section{Materials and Methods}

\section{Market basket design and sample collection}

In order to sample the food products, EU market baskets were created to represent the diet for each of the first 9 months of life of an infant who is not breast fed at all and is fed with commercial baby foods only. Such baskets, that aim to assess the average dietary exposure of infants in the EU, may not capture information on the variability of such exposure. Therefore, additional National market baskets were designed in order to assess the geographical variability. Four countries were selected: Sweden, Italy, Spain and Slovak Republic.

To design the baskets, "Infant formulae and follow-on formulae" and "Other baby foods" products were considered separately and monthly-based diets were elaborated. In the first group of products "Infant formulae" and "follow-on formulae" were considered. Both typologies were represented with three kinds of "Infant formulae and follow-on formulae": milk based formula, 
simulate the progressive introduction in the diet of "Other baby foods" from 5 months of age of an average infant weaned with commercial baby foods only. In the EU, some infants already receive little quantities of complementary foods at 4 months but the majority of infants receive such foods after 6 months of age, as suggested by World Health Organization (Michaelsen K et al. 2003). Moreover a recent opinion by EFSA (2009) states that the introduction of complementary food into the diet of healthy term infants in the EU between the age of 4 and 6 months is safe and does not pose a risk for adverse health effects. Month 5 was therefore chosen to represent the average between fourth and sixth month. From month 5 to month 9 the baskets of "Other baby foods" were varied every month with the addition of new "Other baby foods" products.

Market share data of year 2007 of 22 single countries, for "Infant formulae and follow-on formulae" and "Other baby foods", were purchased from the Company "Food for Thought" (FFT) ([Internet]). For each block of products taken separately, the overall market share of each Holding Company in the 22 countries was taken to represent its market share for these products in the whole EU. For the 4 specific countries, the national market share was used. These data were used to identify the brands of the products to be sampled. The name of the Holding Companies and of their main brands in $22 \mathrm{EU}$ countries was obtained together with their overall market share.

The company FFT was able to provide data for three blocks of products:

- Baby milks: including the 6 categories of baby milks to be sampled ("infant formulae" and "follow-on" of milk formula, soy formula and hypoallergenic formula respectively).

- Baby Jars including: baby food canned, in bottles or in jars, excluding freeze dried products.

- Other Baby Foods including: juices and all dried products such as cereal powders with and without milk, biscuits, dry pasta and any freeze-dried product such as freeze dried meat, freeze dried fish, herbal tea.

The overall market shares for each of these three blocks of products were used as proxy for the specific market shares of the specific products belonging to them.

Products belonging to the last two blocks, "Baby Jars" and "Other Baby Foods" are called in this paper "Other baby foods". They include all liquid and solid commercial baby foods with the exclusion of "Infant formulae and follow-on formulae".

To identify the products and to design the market baskets, different methods have been followed depending on the category of products ("Infant formulae and follow-on formulae" or "Other baby foods") and the typology of the sample (EU or National).

Holding Companies were ranked in decreasing order of market shares and the first companies that cumulatively reached over $80 \%$ were selected. These companies are called 
1 hereafter "leading companies". A check of the websites of these companies showed that they 2 produce and distribute the same (or similar) products in most EU countries. For logistic reasons, 3 the collection of products was therefore tentatively organised in a unique country. Germany was selected. Consequently, the brands of the leading companies that were on the German market were identified. In all cases where a leading company did not have a brand in Germany, an

6 alternative country was selected in which a brand of the same leading company was present.

7 Therefore only a part of products were bought in Germany. The criterion used for the selection 8 of the alternative country was "being the country with the highest estimated number of potential 9 consumers within EU". Demographic data were downloaded from EUROSTAT (2009) 10 ([Internet]) to assess the dimension of the population aged less than 1 year in each of the $22 \mathrm{EU}$ countries. The number of potential consumers was estimated by weighing these data with the market shares of the leading company of interest in each of the 22 countries.

Regarding the National baskets, in order to capture the highest variability in chemical content of the diet, only one brand was identified in each of the four selected countries. It was the main brand from the leading company with the highest market share in that country. If certain categories of product were not produced by this leading company in that particular country, the most popular product (from another Company) sold in the same category was identified. This identification was performed through expert judgement.

"Infant formulae and follow-on formulae" baskets

In order to find the name of all "Infant formulae and follow-on formulae" products of the brands identified, the websites of the brands were searched or the leading companies were contacted.

In term to EU baskets of "Infant formulae and follow-on formulae" the percentage of each product was simply the proportion of market share of each brand among the leading companies. In the event that more than one product was available for one brand, the market share of the specific brand was equally divided by the number of products.

For the National baskets, each typology of product was represented by a unique brand in each of the 4 selected countries and 100 was the percentage of each brand.

\section{"Other baby foods" baskets}

32 The name of the "Other baby foods" products were identified with the help of some CASCADE 33 partners who searched products on their own country market. In order to find the names of the products to be sampled they were suggested to contact a Chemist's who would provide them a list of all products for the brand of interest or to search the websites of the companies or to 
contact the companies. An appropriate database, organised by typology of products was filled

2 by CASCADE partners. The original name of each product and its English translation were

3 recorded together with a brief description of the product and some other information (typology

of packaging, month of introduction as suggested by the producer, main ingredients, ready to eat or powder ).

The following steps were followed to generate the baskets:

A) Identification and assessment of the elements necessary for the elaboration of the diet for EU and National infants from month 5 to month 9:

- Calculation of energy requirements: the standard values of weight for age and sex established by WHO (WHO 2006) and the estimated energy requirements (kcal/kg of body weight/day) set by FAO (FAO 2004) for formula-fed infants were used to calculate the average energy requirements (kcal/day) of infants in the first 9 months of life (Table 1). For the reasons above explained, month 5 was chosen to insert little quantities of complementary foods. It was observed that the average energy intakes assessed by SCF (2003) from the $5^{\text {th }}$ to the $7^{\text {th }}$ months of age for infants fed with both complementary foods and follow-on formula were slightly higher than the energy requirements calculated from FAO (2004) and WHO (2006) (Table 1). Also average body weights were slightly higher. Therefore, in table 1 , for infants of $5^{\text {th }}$ months of age, the energy requirement for 5-6 month ( $622 \mathrm{kcal} /$ day) was considered instead of that for $4-5$ month $(598 \mathrm{kcal} / \mathrm{day})$. The same substitution was also applied for months $6^{\text {th }}$ to $9^{\text {th }}$.

(Table 1here)

- Identification of food categories included in the "Other baby foods" basket for each month of age: in order to establish the month of inclusion of each category of product, the guidelines for infant feeding developed by WHO Europe (Michaelsen K et al. 2003) were considered. However, these guidelines do not provide recommendations at a high level of detail in terms of product categories. The only paediatricians' guidelines providing recommendations at a high level of detail in the European region are those from Switzerland. Therefore, the guidelines of the Swiss Paediatric Society (Société Suisse de Pédiatrie 2002 [Internet]) were used to complement the WHO guidelines. On these bases, a first theoretical schedule of the monthly inclusion of "Other baby foods" was created. The availability of these products in the EU countries was then investigated in order to produce a refined schedule (Figure 1). Thus, in the final 


\section{B) Elaboration of the monthly diets:}

17

Amounts, energy and nutrient content of "follow-on formulae" and "Other baby foods": the estimated average amount of "follow-on formulae" consumed by infants during the $5^{\text {th }}, 6 \mathrm{t}^{\mathrm{h}}$ and $7^{\text {th }}$ month (respectively $600 \mathrm{ml} /$ day, $400 \mathrm{ml} /$ day and $240 \mathrm{ml} /$ day) were taken from a report of Scientific Committee on Food (SCF 2003). These amounts of liquid "follow-on formulae" (ml/day) were translated in gram/day of powder, according to the label of the sampled products, that suggests to use on average $30 \mathrm{ml}$ of water to dilute $4.6 \mathrm{~g}$ of powder of "follow-on formulae" and based on an estimated volumetric density of milk of $1.03 \mathrm{~g} / \mathrm{ml}$ (Di Thomas, 2003). The daily energy intake from "follow-on formulae" was calculated based on its average energy content according to the labels of the products of 8 brands (70.8 $\mathrm{kcal} / 100 \mathrm{~g}$ ). The daily energy intake from "Other baby foods" was then calculated by difference (Table 1$)$.

To calculate the nutrient content of the elaborated diets, the average of values (by typologies of product) reported on labels of 6 brands among the most popular in EU was assessed.

The monthly diets were elaborated in three steps:

1) in terms of main food categories (as infant cereals, pasta, fruits, meat etc...): the diets were designed in grams for each category of "Other baby foods", based on 
the portion sizes suggested by producer labelling and on the meal daily frequency suggested by WHO Europe (Michaelsen et al. 2003), with the exception of "infant cereals" products. The amount of this latter category was calculated by difference from the total calculated energy intake from "Other baby foods" (Table $1)$.

2) in terms of typologies of foods products on the basis of specific features of the products (as Infant cereals without milk and with gluten, Infant cereals with milk, Pureed fruit, Fruit juice, Pulses with vegetables, Fish with vegetables etc...): the

3) in terms of specific products identified: the tables filled in by the responsible person for shopping were used to choose the specific products to be inserted in the EU and National baskets, based on their ingredients. 


\section{C) Creation of the EU and National baskets:}

23 The preparation of the "Other baby foods" baskets, as they were designed initially and above described, would have required collection and sample preparation of a huge number of products and consequently lead to very high costs in terms of time and budget resources. Therefore, a random sampling of brands, weighed on market share, was performed in order to identify only one brand within each typology of product. For the National baskets of "Other baby foods", only the $5^{\text {th }}$ month diet was prepared due to lower number products included compared with month $6^{\text {th }}, 7^{\text {th }}, 8^{\text {th }}$ and $9^{\text {th }}$.

Table 4 shows an example of EU basket of "Infant formulae and follow-on formulae" and "Other baby foods" at month 5 with the products purchased only (the name of the brands were substituted with a code). The other baskets (with all the products selected and with the products purchased only) are not reported as tables in the present paper due to space restrictions but can

For each food typology, the products chosen were the same for all ages of the infants; thus pureed fruit was the same at $5^{\text {th }}, 6^{\text {th }}, 7^{\text {th }}, 8^{\text {th }}$ and $9^{\text {th }}$. The National baskets were designed with a unique product from a unique brand.

The percentages of energy from proteins and lipids were calculated for the monthly diet elaborated and compared with the WHO recommendations (Michaelsen et al. 2003) for infants aged 5-9 months: 14-14.5 g/day of protein Calculation of the percentage of the different products within the sample: the percentage of each brand within the EU and National baskets of "Other baby foods" was simply the proportion of market share of each of the selected leading company that were found to produce a specific product.

With regard to the EU basket, when a typology of product was not available for a certain brand, "0" was assigned as percentage of market share for that leading company and the percentage of the other brands of the same typology were increased proportionally, leading to a "corrected market share". As far as the National baskets were concerned, also in this case, when the selected "leading company" did not distribute a certain category of product in the country, the most popular product of that category sold in the country was identified for sampling. be requested to the corresponding author.

35 (Table 4 here) 
D) Purchase of the products to be sampled

More than half of the products needed to constitute the EU baskets had to be bought in EU countries other than Germany by the CASCADE partners (57\% of "Infant formulae and follow-on formulae" and 55\% of "Other baby foods" products) and delivered to Helmholtz Zentrum München. The other products were bought in Germany, where sample preparations were performed prior analyses.

Pooling, homogenisation, and lyophilisation of the baby foods samples

The pooling of the EU and National basket baby foods samples and related weighting

12 the solid food and beverages were lyophilisated using the freeze drying equipment Type BETA

13 1-16 (Christ $\mathrm{GmbH})$. Overall, the duration of the procedure for each food item was about 36

14 hours. After lyophilisation, the weight of baby food products was reduced with yield varying 15 from 12 to $22 \%$. The proportion of each "Other baby foods" product in the pooled samples was 16 that reported in Table 4. The samples were homogenised in a rotoshaker, Type Reax 20/8 17 (Heidolph $\mathrm{GmbH}$ ) for 8 hours at $10 \mathrm{rpm}$.

18 The samples were kept at room temperature and stored in brown glass jars protected from 19 direct light. In order to prevent any contamination, each further open and close of the sample collector was performed under nitrogen atmosphere.

\section{Results}

23 The number of baskets and of product sampled is reported in Table 5.

\section{"Infant formulae and follow-on formulae" baskets}

26 The first 8 leading companies of "Infant formulae and follow-on formulae" in the EU were 27 selected, covering altogether $82 \%$ of the entire EU market. A total of 42 products were 28 purchased from 6 different countries in order to prepare 6 EU market baskets of "Infant formulae and follow-on formulae".

30 On the other hand, 20 products were purchased to prepare 24 National market baskets of 31 "Infant formulae and follow-on formulae".

\section{Other baby foods baskets}

34 With regard to the baskets of "Other baby foods", the 6 leading companies of the "baby jars" 35 market and the first 7 companies of the "other baby foods" market were selected, covering 
1 altogether respectively $82 \%$ and $81 \%$ of the entire EU market. Nine EU market baskets of

2 "Other baby foods" were designed and 112 products were identified. However because of the

3 above mentioned reasons, only 22 randomly extracted products were sampled from 5 different

4 countries.

5 As far as National baskets of "Other baby foods" are considered, 4 market baskets were 6 elaborated and 47 products were identified. As already mentioned only the basket for the $5^{\text {th }}$ 7 months was prepared, based on a total of 13 products.

8 (Table 5 here)

\section{Discussion and conclusion}

12 Robust estimates of consumer exposure to food chemicals are needed for regulatory chemical 13 risk assessment. Among the main approaches to food chemical intake assessment, WHO 14 recommends the development of a diet model or market basket representing the average diet of 15 the considered population. This model may then be analysed directly for food chemicals of interest (WHO 1999).

Survey market baskets are generally developed on the basis of national food consumption data. It is the case in the U.S (FDA[Internet]), in Australia (FSANZ [Internet]), and in the UK (MAFF [Internet]). A food consumption survey that could be considered representative at EU level is not available. Moreover, in many EU countries, information on exposure to chemical hazards in the diet is collected for the whole population, not specifically for children or infants. The available information is often incomplete or not comparable between EU countries. In order to assess exposure to hazardous chemicals through food, the data collection needs to be harmonized and data need to be collected regularly and to reflect the specific risks to children and infants in the region (ENHIS 2007). For these reasons the methodologies generally used to elaborate national markets baskets have been adapted to the needs of this study. Baskets were designed on the basis of theoretical schemes of insertion of baby foods and of EU market share data for "Infant formulae and follow-on formulae" and "Other baby foods".

The market share data purchased were expressed in value (money) because baby food data expressed in volume (amount of products) were not available at the same level of disaggregation. Although the price of products of the same typology can be different depending on the brand, one leading company can also produce more than one brand destined to different kinds of market (e.g. only for supermarkets with a low or medium price, only for chemists' with 
1 comparable among the companies and data purchased were used as a proxy for market shares in 2 volumes.

Another limitation of the market basket illustrated in the present paper is that the market shares of the specific categories of "baby milks", "baby jars" and "other baby foods" were not available. Thus, since no specific market shares were available for "fruit baby jars" the jars". Moreover, market share data used to identify the brands of the products to be sampled, did not contain private brands (supermarket) and baby foods of this kind of market were not sampled. However, the market share of each of these private brands is known to be low and they would not have been selected as leading brands. In fact, the overall market share of non identified brands of all the baby foods categories considered was $4.5 \%$ including private labels. Since the overall share of such private brands is growing, in future studies one might consider the random extraction of some private brands that would be included in the market basket in proportion to such overall share.

The amount of proteins in the monthly diets here elaborated and expressed in terms of typologies of products was higher than recommended by WHO (up to $11 \%$ versus $9 \%$ ) (Table 4). However, this percentage of protein is lower than that observed in food consumption surveys performed in infants in some European countries: $13.2 \%$ of energy in the UK for infants aged 69 months (Mills et al 1992 ), 11.2-13.2\% of energy in Germany for infants aged 3-9 months (Alexy et al. 1999), 13-14\% of energy in Denmark for infants aged $9^{\mathrm{h}}$ months (Hoppe et al. 2004), 13.3-15.7\% of energy in Spain for infants aged 4-9 months (Capdevila et al. 1998). The amount of proteins in the diets considered in the present paper are therefore intermediate between that recommended by WHO and that observed in consumption surveys.

On the other hand, the percentage of energy from fat was slightly lower than recommended (24-35\% versus 30-40\%), due to the fact that 'added fats' were not considered in the elaboration of the monthly diets.

It is likely that some infants can consume honey since birth. This fact was taken in consideration, but this food was not sampled because honey is not distributed by companies of baby foods.

The lyophilisation of fruity baby foods in jar result a sticky material that caused difficulties in further homogenisation of the samples. As a consequence, these specific products were delivered separately from the other products belonging to the same basket. The further pooling was therefore performed in each testing laboratory itself according above mentioned weighting procedures. 
During the survey, the labels of infant formulae were checked and it appeared that the 2 total energy intake of infants aged 0-4 months could be higher than recommended when the 3 consumer followed instructions reported on the label. This observation has been reported by 4 Pandelova et al., (2009a).

Several samples of "Infant formulae and follow-on formulae" and "Other baby foods",

6 both extracted and non extracted, were prepared and delivered to CASCADE partners for 7 further chemical target analysis, in-vitro and in-vivo testing. The results of some analyses are 8 published (Riu 2008, Pandelova 2009b).

The above described samples of baby foods have been used for the assessment of dietary exposure to a number of substances within the CASCADE project, with the aim of obtaining a realistic panorama of exposure to food chemicals in the infant population, useful for quantitative risk assessment.

14 food consumption patterns of a given population. They may be used to establish specific maximum limits when there is evidence that the health of specific consumers may be at stake (CGSCTFF, 1999). In the present study, a market basket was designed to assess exposure in a very sensible population group: infants. foods: "infant formulae and follow-on formulae" and "other products" and to focus on possible variability at the different ages of the babies and between countries rather than on variability between products categories. Thus, if a food chemical was to be found at a high level of concentration in one or more of the designed baskets it may not be possible to identify the incriminated product category. However, products were purchased in excess so that further analyses on single categories can be performed afterwards. infants in the EU. The food items considered for the elaboration of the monthly diets are those normally consumed by this population group, the quantities were set based on nutritional requirements of infants and the products were purchased in seven different EU countries on the basis of EU market share data collected in 22 countries. The technique could be used again in the future and the exposure data obtained through this methodology could support regulatory actions over time and contribute to the promotion of health of infants fed with commercial foods during early development.

\section{Acknowledgements}


1 The authors would like to thank all CASCADE partners for their assistance in the identification,

2 collection and shipping of baby foods namely Ingemar Pongratz, Lars-Arne Haldosen, Stefan

3 Rehnmark, Nicolas Olea, Jean-Pierre Cravedi and Július Brtko.

4 The study was financially supported by the European Union network CASCADE (FOOD-CT5 2003-506319).

\section{References}

10 Alexy U, Kersting M, Sichert-Hellert W, Manz F, Schöch G. 1999. Macronutrient intake of 311 to 36-month-old German infants and children: results of the DONALD study. Ann Nutr Metab. $12 \quad 43: 14-22$.

14 Capdevila F, Vizmanos B, and Mart'-Henneberg C. 1998. Implications of the weaning pattern

Commission of the European Communities. 1993. Nutrient and energy intakes for the European 24 Community, Reports of the scientific Committee for Food, thirty first series, Office for Official

25 Publications of the European Communities, Luxembourg. (Available at: 26 http://ec.europa.eu/food/fs/sc/scf/out89.pdf).

28 Di Thomas Kardos. 2003. Easy Science Demos \& Labs: Physics. Edition 2. Walch Publishing. 29 35

33 EFSA - European Environment and Health Information System. (2009). Panel on Dietetic 34 Products, Nutrition and Allergies (NDA), Scientific Opinion on the appropriate age for

at: $\underline{\text { http://books.google.it/books?id=GBGS34Aew1gC\&printsec=frontcover\&source=gbs summary }}$ $\mathrm{r} \& \mathrm{cad}=0$ introduction of complementary feeding of infants. EFSA Journal; 7(12): 1423 [38 pp.]. 
1 doi:10.2903/j.efsa.2009.1423.

(Available

online:

2 http://www.efsa.europa.eu/it/efsajournal/doc/1423.pdf)

3

4 ENHIS 2007. Exposure of children to chemical hazards in food 2007. European Environment

8 European Commission. 2006a. Commission Directive 2006/141/EC of 22 December 2006 on

9 infant formulae and follow-on formulae and amending Directive 1999/21/EC (OJ L 401,

10 30.12.2006(Available at:

11 http://ec.europa.eu/food/food/labellingnutrition/children/formulae_en.htm ).

13 European Commission. 2006b Commission Directive 2006/125/EC of 5 December 2006 on 14 processed cereal-based foods and baby foods for infants and young children (OJ L 339/16, 15 6.12.2006). (Available at: http://eur-

16 lex.europa.eu/LexUriServ/LexUriServ.do?uri=OJ:L:2006:339:0016:0035:EN:PDF ).

EUROSTAT. Population and social conditions. [Internet]. Available at: 19 http://epp.eurostat.ec.europa.eu/portal/page/portal/population/data/database . Acceded $20 \mathrm{July}$ 20 2009.

22 FAO. 2004. Food and nutrition technical report series 1: Human energy requirements Report of 23 a Joint FAO/WHO/UNU Expert Consultation, Rome, 17-24 October. Available at: 24 http://www.fao.org/docrep/007/y5686e/y5686e00.HTM .

FDA/Center for Food Safety \& Applied Nutrition [Internet]. Available at: 27 http://www.cfsan.fda.gov/ comm/tds-toc.html _.Acceded 15April 2009.

30 (Switzerland). Available at: http://www.fft.com/fftt/servlet/fftt/template/Index.vm. Acceded $31 \quad 15$ April 2009.

33 FSANZ - Food Standards Australia New Zealand. 22nd Australian Total Diet Study. [Internet]. 34

at: 
1 http://www.foodstandards.gov.au/newsroom/publications/22ndaustraliantotaldietstudy/index.cf

$2 \underline{m}$. Acceded 5 September 2009

3

4 GEMS Food. Total diet studies: A recipe for safer food. [Internet]. 2005. Geneva: World 5 Health Organization. Available at:

6 http://www.who.int/foodsafety/chem/TDS_recipe 2005_en.pdf . Acceded 5 September 2009. 7

8 Hoppe C, Mølgaard C, Thomsen BL, Juul A and Michaelsen KF. 2004. Protein intake at 9 9 month of age is associated with body size but not with body fat in 10-y-old Danish children. Am 10 J Clin Nutr. 79( 3 March): 494-501 .

11

12 MAFF. UK Food Surveillance Information Sheets, 1994 Index to maff, UK food surveillance 13 information sheets $\quad$ [Internet]. Available at: 14 http://archive.food.gov.uk/maff/archive/food/infsheet/1994/no34/34diet.htm. Acceded 16 April $15 \underline{2009}$.

17 Michaelsen K, Weaver L, Branca F and Robertson A. 2003. Feeding and nutrition of infants and 18 young children. Guidelines for the WHO European Region, with emphasis on the former Soviet 19 countries. WHO Regional Publications, European Series, No. 87. Copenhagen: WHO -World 20 Health Organization.

Mills A, Tyler H. 1992. Food and nutrient intakes of British infant aged 6-12 months. HMSO: MAFF. London (UK).

Pandelova ME, Levy Lopez W, Kasham S, Leclercq C, Piccinelli R \& Schramm K-W. 2009a. 26 Assessment of energy intake of infants exclusively fed with infant formulae available on the 27 European market. Int J Food Sci Nutr. 60: 212-219.

Pandelova M, Kasham S, Henkelmann B, Leclercq C, Piccinelli R, Schramm K-W. 2009b. $30 \mathrm{PCDD} / \mathrm{F}$ and dioxin-like PCB level in infant formulae available on the EU market. Proceeding 31 of the 29th International Symposium on Halogenated Persistent Organic Pollutants (POPs), 32 August 23-28, 2009, Beijing, China. 
1 Research and Market. Baby Foods Market Assessment 2006. [Internet]. Oct. 2006. Dublin

2 (Ireland). Available at: http://www.researchandmarkets.com/reportinfo.asp?report_id=461819 .

3 Acceded 16 April 2009.

4

5 Riu A, Balaguer P, Perdu E, Pandelova M, Piccinelli R, Gustafsson J-A, Leclercq C, Schramm

6 K-W, Dagnino S, Debrauwer L, Cravedi J-P, Zalko D. 2008. Characterisation of bioactive

7 compounds in infant formulas using immobilised recombinant estrogen receptor- $\alpha$ affinity

8 columns. Food Chem Toxicol. 46: 3268-3278.

9

10 SCF- Scientific Committee on Food. 2003. SCF/CS/NUT/IF/65 Final 18 May 2003. Report of 11 the Scientific Committee on Food on the revision of essential requirements of infant formula 12 and follow-on formula.

14 Société Suisse de Pédiatrie. 2002. Plan of feeding for newborn baby, infant and toddler up to 36 15 months in good health and without allergy risk. rev.11.2002. [Internet]. Pediatrica. Vol.12 n. 5. 16 Available at: http://www.swiss-paediatrics.org/paediatrica/vol12/n5/iplan-gfi.htm . Acceded15 17 September 2009.

19 WHO -World Health Organization. 1999. Consultations and Workshops: GEMS/Food Total 20 Diet Studies, Report of a Joint USFDA/WHO, WHO/SDE/FOS/99.9. Papers presented at: 21 International Workshop on Total Diet Studies in cooperation with the Pan American Health 22 Organization - Food safety programme department of protection of the human environment 23 World Health Organization. 26 July- 6 August 1999; Kansas City, Missouri, USA. 24

WHO -World Health Organization. 2003. Global strategy for infant and young child 26 feeding. Geneva; (Available at:

27 http://www.who.int/nutrition/publications/gs_infant_feeding_text_eng.pdf ) 28 
Figure 1. Time of inclusion of baby food categories: final schedule used in the design of the CASCADE market baskets of "Other baby foods".

\begin{tabular}{|c|c|c|c|c|c|c|c|c|c|}
\hline \multirow{2}{*}{ FOOD CATEGORIES } & \multicolumn{9}{|c|}{ MONTHS } \\
\hline & 1 & 2 & 3 & 4 & 5 & 6 & 7 & 8 & 9 \\
\hline \multicolumn{10}{|l|}{ INFANT FORMULAE FOLLOW-ON } \\
\hline \multicolumn{10}{|l|}{ INFANT CEREALS: } \\
\hline \multicolumn{10}{|l|}{ INFANT CEREALS without gluten } \\
\hline \multicolumn{10}{|l|}{ INFANT CEREALS with gluten } \\
\hline \multicolumn{10}{|l|}{ INFANT CEREALS with milk } \\
\hline \multicolumn{10}{|l|}{ PASTA } \\
\hline \multicolumn{10}{|l|}{ BISCUITS } \\
\hline \multicolumn{10}{|l|}{ FRUIT: } \\
\hline \multicolumn{10}{|l|}{ PUREED FRUIT } \\
\hline \multicolumn{10}{|l|}{ FRUIT JUICE } \\
\hline \multicolumn{10}{|l|}{ VEGETABLES/POTATOES } \\
\hline \multicolumn{10}{|l|}{ PULSES } \\
\hline \multicolumn{10}{|l|}{ MEAT } \\
\hline \multicolumn{10}{|l|}{ FISH } \\
\hline \multicolumn{10}{|l|}{ DAIRY BASED DESSERT: } \\
\hline \multicolumn{10}{|l|}{ DAIRY BASED DESSERT with fruit } \\
\hline DAIRY BASED DESSERT with chocolate & & & & & & & & & \\
\hline ADDED FATS (OIL/BUTTER etc...) & & & & & & & & & \\
\hline
\end{tabular}


Table 1. Calculated average energy requirement ( $\mathrm{kcal} /$ day) by age class in infants aged 0 to 10 months, SCF data from $5^{\text {th }}$ to $9^{\text {th }}$ month and calculated daily energy intake from "Infant formulae and follow-on formulae" (follow-on) and "Other baby foods"

(1) Average body weight in infants of age between month $\mathrm{x}$ and month $\mathrm{x}+1$ was estimated by calculating 1) the average of 50th percentile at month $x$ and month $x+1$ in both females and males, according to WHO 2006 and 2) by calculating the average between the values obtained in females and males.

(2) FAO 2004.

(3) For infants of 5 months of age, calculated average energy requirement for 5-6 month (622 kcal/day) was used instead of that for $4-5$ month (598 kcal/day). The same was performed for 6th to 9 th months of age.

(4) SCF 2003.

(5) Energy intake from infant formulae was calculated multiplying the average of the energy content reported on the labels of sampled products (on average, $100 \mathrm{~g}$ of rehydrated infant formulae follow-on contain 71 $\mathrm{kcal}$ ) by the amount of infant formula (ml/day) consumed by infants during the $5 \mathrm{~h}$, 6th and $7 \mathrm{~h}$ month (SCF 2003); the amount of infant formulae follow-on consumed at 8 th and 9 th month is assumed to be the same as that consumed at 7 th month (one baby bottle).

(6 )Energy intake from "Other baby foods" were calculated by subtracting the energy intake deriving from

"Infant formulae" from the calculated average energy requirements 
Table 2. Categories and typologies of baby foods chosen to design baskets from $5^{\text {th }}$ and $9^{\text {th }}$ month.

\begin{tabular}{|c|c|c|}
\hline FOOD CATEGORY & TYPOLOGY OF FOOD PRODUCTS & $\begin{array}{l}\text { SPECIFIC FEATURES OF THE } \\
\text { TYPOLOGIES OF PRODUCTS }\end{array}$ \\
\hline $\begin{array}{l}\text { INFANT FORMULAE AND } \\
\text { FOLLOW-ON FORMULAE }\end{array}$ & Infant formula follow-on & Infant formula follow on - in powder \\
\hline \multicolumn{3}{|l|}{ INFANT CEREALS: } \\
\hline & $\begin{array}{l}\text { Infant cereals without milk and without } \\
\text { gluten }\end{array}$ & Rice - in powder \\
\hline & $\begin{array}{l}\text { Infant cereals without milk and with } \\
\text { gluten }\end{array}$ & $\begin{array}{l}\text { Multicereals or cereals with gluten- in } \\
\text { powder }\end{array}$ \\
\hline & Infant cereals with milk & $\begin{array}{l}\text { Infant cereals with milk and fruit or } \\
\text { honey - in powder }\end{array}$ \\
\hline PASTA & Rice or pasta with meat and vegetables & $\begin{array}{l}\text { Rice or pasta (around } 20 \% \text { ) with meat } \\
\text { (veal and/or chicken and/or turkey) } \\
\text { (around } 20 \% \text { ) and vegetables (around } \\
60 \% \text { - where available with potatoes - } \\
\text { in jars (ready to eat) }\end{array}$ \\
\hline BISCUITS & Infant biscuits & Biscuits with gluten - No granular \\
\hline \multicolumn{3}{|l|}{ FRUIT: } \\
\hline & Pureed fruit & $\begin{array}{l}\text { Fruit mix with two fruit among apple } \\
\text { and/or pear and/or banana and/or } \\
\text { apricot- in jars (ready to eat) }\end{array}$ \\
\hline & Fruit juice & $\begin{array}{l}\text { Apricot or other if not available - } \\
\text { liquid (ready to eat) }\end{array}$ \\
\hline PULSES/VEGETABLES & Pulses with vegetables & $\begin{array}{l}\text { Pulses (around } 40 \% \text { ) and vegetables } \\
\text { (around } 60 \% \text { )- where available with } \\
\text { potatoes - in jars (ready to eat) }\end{array}$ \\
\hline FISH & Fish with vegetables & $\begin{array}{l}\text { Fish (sole and/or salmon and/or } \\
\text { codfish) (around } 40 \% \text { ) with vegetables } \\
\text { (around } 60 \% \text { ) - where available with } \\
\text { potatoes- in jars (ready to eat) }\end{array}$ \\
\hline MEAT & Meat with vegetables & $\begin{array}{l}\text { Meat (veal and/or chicken and/or } \\
\text { turkey) (around } 40 \% \text { ) with vegetables } \\
\text { (around } 60 \% \text { ) - where available with } \\
\text { potatoes - in jars (ready to eat) }\end{array}$ \\
\hline DAIRY BASED DESSERT & Dairy based dessert & $\begin{array}{l}\text { Milk or cheese based dessert with } \\
\text { forest fruit or chocolate - in jars (ready } \\
\text { to eat) }\end{array}$ \\
\hline
\end{tabular}


Table 3. Theoretical diets elaborated in terms of main food categories and of typologies of commercial baby foods (months 5-9).

\begin{tabular}{|c|c|c|c|c|c|}
\hline \multicolumn{2}{|c|}{$\begin{array}{c}\text { DIET IN TERMS OF } \\
\text { MAIN FOOD CATEGORIES }\end{array}$} & \multicolumn{4}{|c|}{$\begin{array}{c}\text { DIET IN TERMS OF } \\
\text { TYPOLOGIES OF FOOD PRODUCTS }\end{array}$} \\
\hline CATEGORIES & $\begin{array}{l}\text { Daily consumption } \\
{\text { (g/day })^{(1)}}^{\text {(g/on }}\end{array}$ & $\begin{array}{c}\text { Energy } \\
(\mathrm{kcal})\end{array}$ & TYPOLOGIES & $\begin{array}{l}\text { Daily } \\
\text { consumption } \\
\text { (g/day) }\end{array}$ & $\begin{array}{c}\text { Energy } \\
(\mathrm{kcal})\end{array}$ \\
\hline \multicolumn{6}{|l|}{$5^{\text {th }} \mathrm{MONTH}$} \\
\hline $\begin{array}{l}\text { Infant formulae and follow-on } \\
\text { formulae }\end{array}$ & $89(600)^{(2)}$ & 425 & $\begin{array}{l}\text { Infant formulae follow-on } \\
\text { (powder) }\end{array}$ & $89(600)^{(2)}$ & 425 \\
\hline Infant cereals ${ }^{(3)}$ & 12 & 44 & $\begin{array}{l}\text { Infant cereals without milk } \\
\text { and without gluten (powder) }\end{array}$ & 20 & 74 \\
\hline Fruit & 80 & 59 & Pureed fruit (jar) & 80 & 59 \\
\hline Vegetables & 40 & 19 & Meat $^{(5)}+$ vegetables & & \\
\hline Meat & 40 & 33 & + potatoes (jar) & 100 & 63 \\
\hline Added fats (oil/butter etc..) $)^{(4)}$ & 5 & 41 & & & \\
\hline Total & & 622 & Total & & 622 \\
\hline \multicolumn{6}{|l|}{$6^{\text {th }}$ MONTH } \\
\hline $\begin{array}{l}\text { Infant formulae and follow-on } \\
\text { formulae }\end{array}$ & $60(400)^{(2)}$ & 283 & $\begin{array}{l}\text { Infant formulae follow-on } \\
\text { (powder) }\end{array}$ & $60(400)^{(2)}$ & 283 \\
\hline \multirow{2}{*}{ Infant cereals ${ }^{(3)}$} & \multirow{2}{*}{33} & \multirow{2}{*}{126} & $\begin{array}{l}\text { Infant cereals without milk } \\
\text { and without gluten (powder) }\end{array}$ & 15 & 57 \\
\hline & & & $\begin{array}{l}\text { Infant cereals without milk } \\
\text { and with gluten (powder) }\end{array}$ & 15 & 56 \\
\hline Fruit & 100 & 74 & $\begin{array}{l}\text { Pureed fruit (jar) } \\
\text { Fruit juice (liquid) }\end{array}$ & $\begin{array}{l}75 \\
25\end{array}$ & $\begin{array}{l}56 \\
14\end{array}$ \\
\hline Vegetables/ Pulses & 80 & 39 & $\begin{array}{l}\text { Meat }{ }^{(5)}+\text { vegetables } \\
\text { +potatoes (jar) }\end{array}$ & 200 & 126 \\
\hline Meat & 80 & 65 & $\begin{array}{l}\text { Pulses+vegetables+potatoes } \\
\text { (jar) }\end{array}$ & 75 & 38 \\
\hline Added fats (oil/butter etc..) ${ }^{(4)}$ & 5 & 41 & & & \\
\hline Total & & 630 & Total & & 630 \\
\hline
\end{tabular}

(1) The theoretical diets were designed in order to ensure that the energy intake from "Infant formulae and follow-on formulae" and from "Other baby foods" were in line with those reported in table 2.

(2) In parenthesis consumption of "Infant formulae" expressed in ml/day of product ready to be consumed.

(3) The amount of this food category was calculated by difference from the calculated energy intake from "Other baby foods" (Table 3).

(4) "Added fats (oil/butter etc..)" were not sampled, since they are present in commercial baby foods mixed dishes and no such products specifically designed for babies were found to be available in any EU country.

(5) The total quantity of jars containing meat was calculated to ensure the daily consumption of the portion size of meat considered in the theoretical diets elaborated in terms of main food categories. 
Table 3 (continued). Theoretical diets elaborated in terms of main food categories and of typologies of commercial baby foods (months 5-9).

\begin{tabular}{|c|c|c|c|c|c|}
\hline \multicolumn{3}{|c|}{$\begin{array}{c}\text { DIET IN TERMS OF } \\
\text { MAIN FOOD CATEGORIES }\end{array}$} & \multicolumn{3}{|c|}{$\begin{array}{c}\text { DIET IN TERMS OF } \\
\text { TYPOLOGIES OF FOOD PRODUCTS }\end{array}$} \\
\hline CATEGORIES & $\begin{array}{l}\text { Daily } \\
\text { consumption } \\
{\text { (g/day })^{(1)}}^{\left({ }^{2}\right.}\end{array}$ & $\begin{array}{l}\text { Energy } \\
(\mathrm{kcal})\end{array}$ & TYPOLOGIES & $\begin{array}{l}\text { Daily } \\
\text { consumption } \\
\text { (g/day) }\end{array}$ & $\begin{array}{c}\text { Energy } \\
(\mathrm{kcal})\end{array}$ \\
\hline \multicolumn{6}{|l|}{$7^{\text {th }}$ MONTH } \\
\hline $\begin{array}{l}\text { Infant formulae and follow-on } \\
\text { formulae }\end{array}$ & $36(240)^{(2)}$ & 170 & $\begin{array}{l}\text { Infant formulae follow- } \\
\text { on (powder) }\end{array}$ & $36(240)^{(2)}$ & 170 \\
\hline \multirow{3}{*}{ Infant cereals ${ }^{(3)}$} & \multirow{3}{*}{27} & \multirow{3}{*}{101} & $\begin{array}{l}\text { Infant cereals without } \\
\text { milk and without gluten } \\
\text { (powder) }\end{array}$ & 10 & 38 \\
\hline & & & $\begin{array}{l}\text { Infant cereals without } \\
\text { milk and with gluten } \\
\text { (powder) }\end{array}$ & 20 & 75 \\
\hline & & & $\begin{array}{l}\text { Infant cereals with milk } \\
\text { and fruit (powder) }\end{array}$ & 10 & 36 \\
\hline \multirow{2}{*}{ Fruit } & \multirow{2}{*}{160} & \multirow{2}{*}{118} & Pureed fruit (jar) & 120 & 89 \\
\hline & & & Fruit juice (liquid) & 40 & 22 \\
\hline Pasta & 20 & 71 & $\begin{array}{l}\text { Pasta }+ \text { meat +vegetables } \\
\text { +potatoes (jar) }\end{array}$ & 100 & 63 \\
\hline Vegetables/ Pulses & 100 & 49 & $\begin{array}{l}\text { Pulses +vegetables } \\
\text { +potatoes (jar) }\end{array}$ & 75 & 38 \\
\hline Meat & 80 & 65 & $\begin{array}{l}\text { Meat }{ }^{(5)}+\text { vegetables } \\
\text { +potatoes (jar) }\end{array}$ & 150 & 95 \\
\hline Dairy based dessert & 40 & 40 & $\begin{array}{l}\text { Dairy based dessert (with } \\
\text { fruit) (jar) }\end{array}$ & 40 & 39 \\
\hline Added fats (oil/butter etc..) ${ }^{(4)}$ & 5 & 41 & & & \\
\hline Total & & 656 & Total & 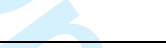 & 665 \\
\hline \multicolumn{6}{|l|}{$8^{\text {th }}$ MONTH } \\
\hline $\begin{array}{l}\text { Infant formulae and follow-on } \\
\text { formulae }\end{array}$ & $36(240)^{(2)}$ & 170 & $\begin{array}{l}\text { Infant formulae follow- } \\
\text { on (powder) }\end{array}$ & $36(240)^{(2)}$ & 170 \\
\hline \multirow{3}{*}{ Infant cereal ${ }^{(3)}$} & \multirow{3}{*}{26} & \multirow{3}{*}{99} & $\begin{array}{l}\text { Infant cereals without } \\
\text { milk and without gluten } \\
\text { (powder) }\end{array}$ & 9 & 33 \\
\hline & & & $\begin{array}{l}\text { Infant cereals without } \\
\text { milk and with gluten } \\
\text { (powder) }\end{array}$ & 18 & 66 \\
\hline & & & $\begin{array}{l}\text { Infant cereals with milk } \\
\text { and fruit (powder) }\end{array}$ & 9 & 32 \\
\hline Biscuits & 8 & 33 & Baby biscuits & 8 & 33 \\
\hline \multirow{2}{*}{ Fruit } & \multirow{2}{*}{160} & \multirow{2}{*}{118} & Pureed fruit (jar) & 120 & 89 \\
\hline & & & Fruit juice (liquid) & 40 & 22 \\
\hline Pasta & 20 & 71 & $\begin{array}{l}\text { Pasta }+ \text { meat }+ \text { vegetables } \\
\text { + potatoes (jar) }\end{array}$ & 100 & 63 \\
\hline Vegetables/ Pulses & 100 & 49 & $\begin{array}{l}\text { Pulses + vegetables }+ \\
\text { Potatoes (jar) }\end{array}$ & 75 & 38 \\
\hline
\end{tabular}


(1) The theoretical diets were designed in order to ensure that the energy intake from "Infant formulae and follow-on formulae" and from "Other baby foods" were in line with those reported in table 2.

(2) In parenthesis consumption of "Infant formulae" expressed in ml/day of product ready to be consumed.

(3) The amount of this food category was calculated by difference from the calculated energy intake from "Other baby foods" (Table 3).

(4) "Added fats (oil/butter etc..)" were not sampled, since they are present in commercial baby foods mixed dishes and no such products specifically designed for babies were found to be available in any EU country.

(5) The total quantity of jars containing meat was calculated to ensure the daily consumption of the portion size of meat considered in the theoretical diets elaborated in terms of main food categories. 
Table 3 (continued). Theoretical diets elaborated in terms of main food categories and of typologies of commercial baby foods (months 5-9).

\begin{tabular}{|c|c|c|c|c|c|}
\hline \multicolumn{3}{|c|}{$\begin{array}{c}\text { DIET IN TERMS OF } \\
\text { MAIN FOOD CATEGORIES }\end{array}$} & \multicolumn{3}{|c|}{$\begin{array}{c}\text { DIET IN TERMS OF } \\
\text { TYPOLOGIES OF FOOD PRODUCTS }\end{array}$} \\
\hline CATEGORIES & $\begin{array}{c}\text { Daily } \\
\text { consumption } \\
\text { (g/day) }^{(1)} \\
\end{array}$ & $\begin{array}{l}\text { Energy } \\
\text { (kcal) }\end{array}$ & TYPOLOGIES & $\begin{array}{c}\text { Daily } \\
\text { consumption } \\
\text { (g/day) }\end{array}$ & $\begin{array}{c}\text { Energy } \\
(\mathrm{kcal})\end{array}$ \\
\hline \multicolumn{6}{|l|}{$9^{\text {h }}$ MONTH } \\
\hline $\begin{array}{l}\text { Infant formulae and follow-on } \\
\text { formulae }\end{array}$ & $36(240)^{(2)}$ & 170 & $\begin{array}{l}\text { infant formulae follow-on } \\
\text { (powder) }\end{array}$ & $36(240)^{(2)}$ & 170 \\
\hline \multirow{3}{*}{ Infant cereals ${ }^{(3)}$} & \multirow{3}{*}{22} & \multirow{3}{*}{83} & $\begin{array}{l}\text { Infant cereals without milk } \\
\text { and without gluten } \\
\text { (powder) }\end{array}$ & 8 & 28 \\
\hline & & & $\begin{array}{l}\text { Infant cereals without milk } \\
\text { and with gluten (powder) }\end{array}$ & 15 & 56 \\
\hline & & & $\begin{array}{l}\text { Infant cereals with milk and } \\
\text { fruit (powder) }\end{array}$ & 8 & 27 \\
\hline Biscuits & 8 & 33 & Baby biscuits & 8 & 33 \\
\hline \multirow{2}{*}{ Fruit } & \multirow{2}{*}{160} & \multirow{2}{*}{118} & \multirow{2}{*}{$\begin{array}{l}\text { Pureed fruit (jar) } \\
\text { Fruit juice (liquid) }\end{array}$} & 120 & 89 \\
\hline & & & & 40 & 22 \\
\hline Pasta & 20 & 71 & $\begin{array}{l}\text { Pasta }+ \text { meat +vegetables } \\
\text { +potatoes (jar) }\end{array}$ & 100 & 63 \\
\hline Vegetables/ Pulses & 100 & 49 & $\begin{array}{l}\text { Pulses + vegetables + } \\
\text { potatoes (jar) }\end{array}$ & 75 & 38 \\
\hline Meat & 50 & 41 & $\begin{array}{l}\text { Meat }(5)+\text { vegetables } \\
\text { +potatoes (jar) }\end{array}$ & 75 & 47 \\
\hline Fish & 30 & 18 & $\begin{array}{l}\text { Fish +vegetables + potatoes } \\
\text { (jar) }\end{array}$ & 75 & 49 \\
\hline \multirow{2}{*}{ Dairy based dessert } & \multirow{2}{*}{80} & \multirow{2}{*}{80} & $\begin{array}{l}\text { Dairy based dessert (with } \\
\text { fruit) (jar) }\end{array}$ & 60 & 59 \\
\hline & & & $\begin{array}{l}\text { Dairy based dessert (with } \\
\text { chocolate) (jar) }\end{array}$ & 20 & 20 \\
\hline \multirow[t]{2}{*}{ Oil/butter ${ }^{(4)}$} & 5 & 41 & & & \\
\hline & & 705 & \multicolumn{2}{|l|}{ Total } & 701 \\
\hline
\end{tabular}

(1) The theoretical diets were designed in order to ensure that the energy intake from "Infant formulae and follow-on formulae" and from "Other baby foods" were in line with those reported in table 2.

(2) In parenthesis consumption of "Infant formulae" expressed in ml/day of product ready to be consumed.

(3) The amount of this food category was calculated by difference from the calculated energy intake from "Other baby foods" (Table 3).

(4) "Added fats (oil/butter etc..)" were not sampled, since they are present in commercial baby foods mixed dishes and no such products specifically designed for babies were found to be available in any EU country.

(5) The total quantity of jars containing meat was calculated to ensure the daily consumption of the portion size of meat considered in the theoretical diets elaborated in terms of main food categories. 
Table 4. EU basket of "Infant formulae and follow-on formulae" and "Other baby foods" at month 5, as sampled within the CASCADE project - with milk based infant formula follow-on.

\begin{tabular}{|c|c|c|c|c|c|c|c|c|c|c|c|c|}
\hline \multirow[b]{2}{*}{ 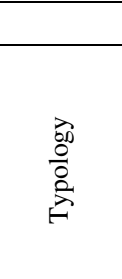 } & \multicolumn{3}{|c|}{ DIET } & \multicolumn{9}{|c|}{ MARKET BASKET } \\
\hline & 氙 & $\begin{array}{l}\frac{0}{7} \\
\frac{0}{0} \\
0 \\
0 \\
0 \\
0\end{array}$ & 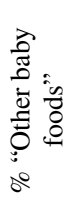 & 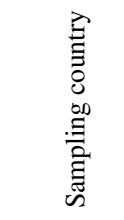 & 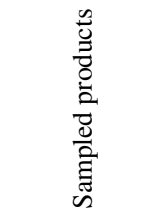 & 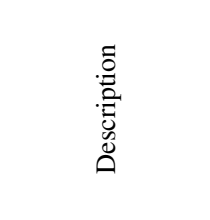 & 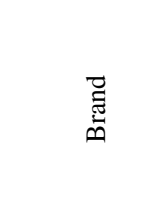 & 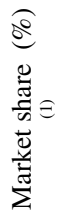 & 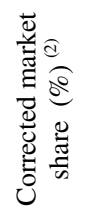 & 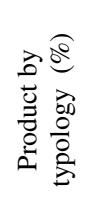 & 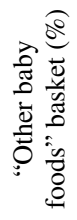 & 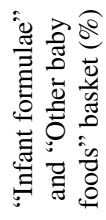 \\
\hline \multirow{13}{*}{$\begin{array}{l}\text { Milk } \\
\text { based } \\
\text { infant } \\
\text { formula } \\
\text { follow on }\end{array}$} & 89 & 68.3 & & & & & & & & & & \\
\hline & & & & Germany & Product 1 & & BRAND A & 27.9 & 13.95 & 17.0 & & 11.58 \\
\hline & & & & Germany & Product 2 & & BRAND A & & 13.95 & 17.0 & & 11.58 \\
\hline & & & & Germany & Product 3 & & BRAND B & 26.5 & 26.5 & 32.2 & & 22.00 \\
\hline & & & & UK & Product 4 & & BRAND D & 9.3 & 9.3 & 11.3 & & 7.72 \\
\hline & & & & France & Product 5 & & BRAND F & 5.9 & 5.9 & 7.2 & & 4.90 \\
\hline & & & & Sweden & Product 6 & & BRAND H & 3.6 & 3.6 & 4.4 & & 2.99 \\
\hline & & & & Germany & Product 7 & & BRAND C & 3.4 & 3.4 & 4.1 & & 2.82 \\
\hline & & & & France & Product 8 & & BRAND G & 3 & 3 & 3.6 & & 2.49 \\
\hline & & & & Italy & Product 9 & & BRAND I_1 & 2.7 & 0.9 & 1.1 & & 0.75 \\
\hline & & & & Italy & Product 10 & & BRAND I_3 & & 0.9 & 1.1 & & 0.75 \\
\hline & & & & Italy & Product 11 & & BRAND I_2 & & 0.9 & 1.1 & & 0.75 \\
\hline & & & & & Total & & & 82.3 & 82.3 & 100.0 & & 68.33 \\
\hline \multirow{2}{*}{$\begin{array}{l}\text { Infant } \\
\text { cereals } \\
\text { without } \\
\text { gluten } \\
\text { and } \\
\text { without } \\
\text { milk }\end{array}$} & 20 & 11.9 & 37.7 & & & & & & & & & \\
\hline & & & & France & Product 12 & $\begin{array}{l}\text { rice vanilla } \\
\text { flavour }\end{array}$ & BRAND F & & & 100.0 & 37.8 & 12.00 \\
\hline \multirow[t]{4}{*}{$\begin{array}{l}\text { Pureed } \\
\text { Fruit }\end{array}$} & 80 & 9.6 & 30.2 & & & & & & & & & \\
\hline & & & & Germany & Product 13 & $\begin{array}{l}\text { peaches and } \\
\text { apple and } \\
\text { apricots }\end{array}$ & BRAND B & & & 50.0 & 15.1 & 4.78 \\
\hline & & & & Germany & Product 14 & $\begin{array}{l}\text { fruit peaches, } \\
\text { apricots, apple }\end{array}$ & BRAND B & & & 50.0 & 15.1 & 4.78 \\
\hline & & & & & Total & & & & & 100.0 & 30.2 & 9.56 \\
\hline \multirow{7}{*}{$\begin{array}{l}\text { Meat } \\
\text { +vegetabl } \\
\text { es } \\
\text { +potatoes } \\
\text { (3) }\end{array}$} & 100 & 10.2 & 32.1 & & & & & & & & & \\
\hline & & & & Italy & Product 15 & beef/chicken & BRAND I_1 & & & 16.7 & 5.3 & 1.69 \\
\hline & & & & Italy & Product 16 & beef/chicken & BRAND I_3 & & & 16.7 & 5.3 & 1.69 \\
\hline & & & & Italy & Product 17 & beef/chicken & BRAND I_2 & & & 16.7 & 5.3 & 1.69 \\
\hline & & & & Italy & Product 18 & mixed vegetables & BRAND I_1 & & & 50.0 & 16.0 & 5.08 \\
\hline & & & & & Total & & & & & 100.0 & 32.9 & 10.15 \\
\hline & & 100 & 100 & & & & & & & & & \\
\hline
\end{tabular}

(1) Data referred to 2007, purchased from the Company "Food for Thought" (FFT) (http://www.fft.com/fftt/servlet/fftt/template/Index.vm).

(2) In the event that more than one product was available for one brand, the percentage of each brand was equally divided by the number of products.

(3) Meat jars of the sampled company do not contein vegetables. As a consequence the typologies "meat + vegetables +potatoes" was obtained by combining meat jars and vegetables jars. 
Table 5. Number of baskets created and of products purchased within the CASCADE project.

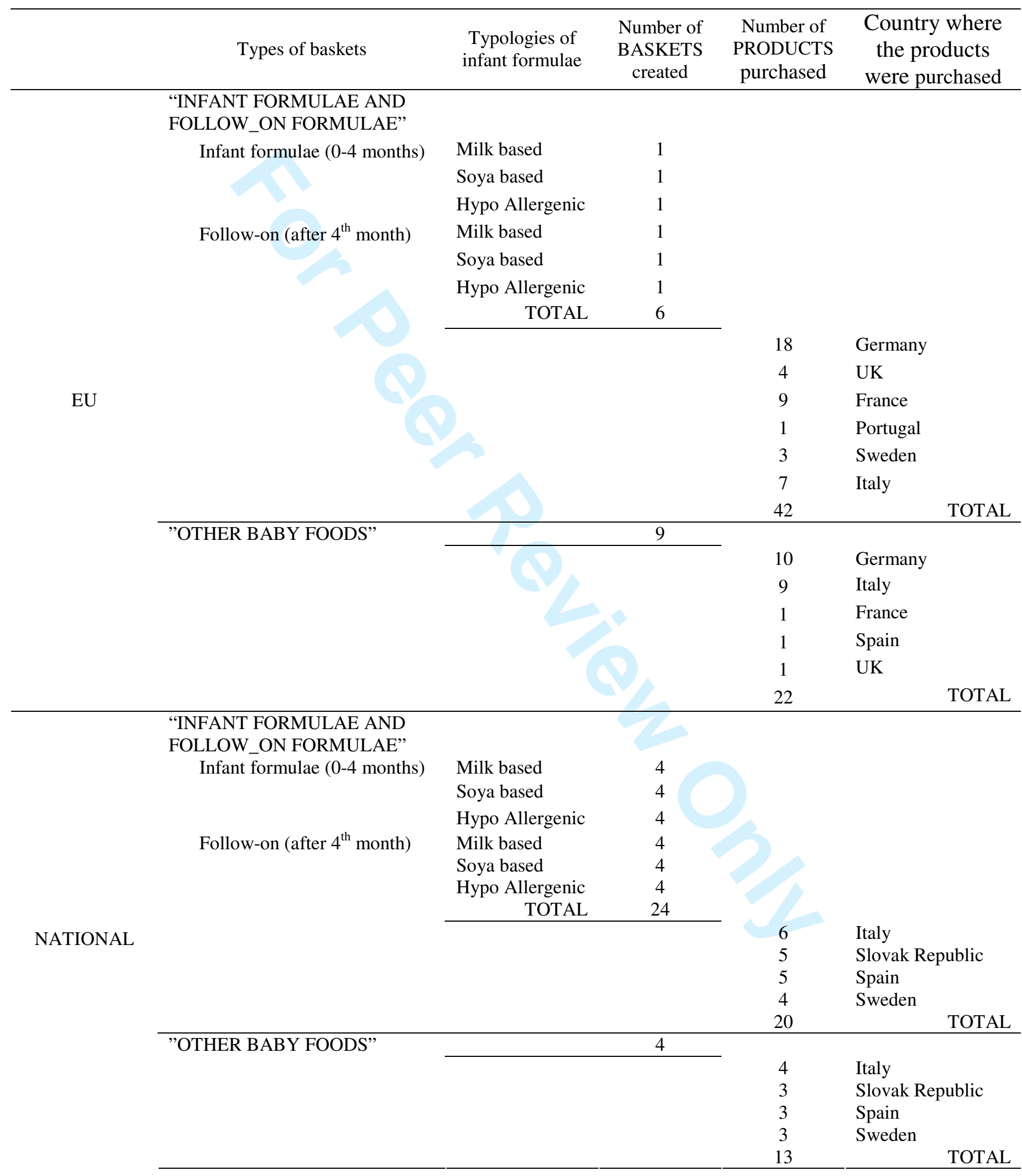


